\title{
Stem cell analysis with intraductally treated mammary epithelial cells
}

\author{
Ah Young Yoon ${ }^{1}$, Yun Young Kim ${ }^{1,2}$, Joon-Hyop Lee ${ }^{1,2}$, Yoo Seung Chung ${ }^{1,2}$, Sangtae Choi ${ }^{1,2}$, Jin Mo Kang ${ }^{1,2}$, Heung Kyu Park ${ }^{1,2}$, \\ Yong Soon Chun ${ }^{1,2}$ \\ 'Department of Surgery, Gachon University Gil Medical Center, Incheon; \\ ${ }^{2}$ Department of Surgery, Gachon University College of Medicine, Incheon, Korea
}

Purpose: The activity of mammary stem cells (MaSCs) is essential to mammary growth, differentiation and regeneration in cycles of pregnancy, lactation, and involution. The capability to recruit the mammary gland through the cycles is attributed to stem cells. It was shown that the intraductal (i.duc) injection of pegylated liposomal doxorubicin (PLD) to multiparous FVB/N mice was associated with a significantly reduced outgrowth potential of mammary gland cells. We have explored i.duc PLD's effect on stem cell number and function in mouse mammary gland and aldehyde dehydrogenase (ALDH)'s availability as a mouse MaSC marker.

Methods: The total mammary epithelium was purified from 6 to 8-month-old FVB/N control and i.duc PLD-administered mice treated twice and analyzed by flow cytometry and limiting dilution cleared mammary fat pad transplants.

Results: There was no significant difference in the proportions of stem cell-enriched population (CD49f ${ }^{\text {high }}$ CD24 ${ }^{\text {med }}$ ) between control and i.duc PLD-treated groups. However, we found a significant reduction in the outgrowth potential of $C D 49 f^{\text {high }} \mathrm{CD} 24^{\text {med }}$ and $\mathrm{CD} 49$ f $^{\text {high }} \mathrm{CD} 24^{\text {med }} \mathrm{ALDH}(+)$ cells from i.duc PLD-treated mammary glands. We discovered that adding ALDH to CD49f ${ }^{\text {high }} \mathrm{CD} 24^{\text {med }}$ had the possibility of better marker selection for MaSC of mice.

Conclusion: We present i.duc administration of PLD to reduce MaSC function, but not the number; and ALDH activity may add further selection of MaSCs to CD49f CD24 in mouse mammary glands. Screening of chemotherapeutic drugs or other natural products by this method of stem cell analysis may provide safe i.duc treatment in breast cancer.

Keywords: Intraductal, Mammary stem cell, Aldehyde dehydrogenase, CD49f, CD24

Received: Jun 06, 2019 Revised: Jun 19, 2019 Accepted: Jun 21, 2019

Correspondence to: Yong Soon Chun

Department of Surgery, Gachon University Gil Medical Center, Gachon

University College of Medicine, 21 Namdong-daero 774beon-gil,

Namdong-gu, Incheon 21565, Korea

Tel: +82-32-458-2731, Fax: +82-32-460-3247

E-mail: chunysmd@gachon.ac.kr

ORCID: Ah Young Yoon (https://orcid.org/0000-0002-3710-8950), Yun Young Kim (https://orcid.org/0000-0002-0077-540X), Joon-Hyop Lee (https://orcid.org/00000003-0470-7719), Yoo Seung Chung (https://orcid.org/0000-0001-9912-051X), Sangtae Choi (https://orcid.org/0000-0002-2074-1733), Jin Mo Kang (https:// orcid.org/0000-0002-1477-9778), Heung Kyu Park (https://orcid.org/0000-00028284-9221), Yong Soon Chun (https://orcid.org/0000-0002-7094-677X)

*This article was presented at 67th Annual Congress of the Korean Surgical Society 2015, on November 5-7, 2015, in Seoul, Korea.

Copyright @ 2019 Korean Society of Surgical Oncology

This is an Open Access article distributed under the terms of the Creative Commons Attribution Non-Commercial License (http://creativecommons.org/licenses/by-nc/4.0) which permits unrestricted non-commercial use, distribution, and reproduction in any medium, provided the original work is properly cited.

\section{INTRODUCTION}

Since the majority of breast cancers originate in the epithelial cells lining the duct, it was hypothesized that administration of agents directly into the breast ductal system (intraductal; i.duc) may result in eradication of premalignant disease, and prevention of the development of new lesions. In preclinical models, it was previously demonstrated that the i.duc administration of 4-hydroxytamoxifen or pegylated liposomal doxorubicin (PLD) to carcinogen-induced mammary tumors in rodents was associated with a reduction in mammary tumor volume, eradication of pre-malignant disease, and prevention of new lesions [1]. The i.duc administration of several other chemotherapeutic agents was tested in methylnitrosourea (MNU)-injected rats and both fluorouracil (5-FU) and carboplatin were proved to be effective [2]. We demonstrated that i.duc nanocurcumin prevented the development of mammary tumors efficiently in carcinogen-induced rat models [3]. We re- 
ported that i.duc PLD injection reduces normal mammary stem cells (MaSCs)' function, which results in disturbing milk production in lactating mouse mammary gland and inducing malignant tumor [4]. Mouse MaSCs have been reported to be enriched in the subset of mammary cells that are $\mathrm{Lin}^{-} \mathrm{CD} 49 \mathrm{f}^{\text {high }} \mathrm{CD} 24^{\mathrm{med}}$ or $\mathrm{Lin}^{-}$ $\mathrm{CD} 29^{\text {high }} \mathrm{CD} 24^{\text {med }}[5,6]$. However, the poor level of stem cell enrichment makes it doubtful that changes in the number of stem cells can be detected by examining these stem cell-enriched populations as a whole. It was suggested that flow cytometry using more specific stem cell markers may solve this problem [7].

Here we have explored i.duc PLD's effect on stem cell number and function in mouse mammary gland and aldehyde dehydrogenase (ALDH)'s availability as a mouse MaSC marker. We have studied the utility of this stem cell analysis as a screening method to check the safety of i.duc treatment in breast cancer.

\section{METHODS}

\section{Animals, animal surgery and treatment}

Six-month-old to 8-month-old postbreeder FVB/N mice were purchased from National Cancer Institute at Frederick, USA and maintained in our animal facility according to institutional guidelines. All experiments were performed with approval of the Animal Care and Use Committee of Johns Hopkins University School of Medicine.

\section{Intraductal injection}

Mice were anesthetized by isoflurane/oxygen inhalation. Keratin plugs were removed from the surface of the nipple by rubbing gently with gauze soaked in alcohol, revealing the duct orifice. Mammary ducts were cannulated using a 1.0-cm, 34-gauge, blunt-ended needle (Hamilton 7741-01; Reno, NV, USA) attached to a $50 \mu \mathrm{L}$ tuberculin syringe. PLD ( $50 \mu \mathrm{L} / \mathrm{duct})$ was injected slowly into the duct while visualizing the opening under a dissecting microscope.

\section{Anticancer agent}

PLD was used for experiments. For the stem cell analysis, FVB/N mice were used and $40 \mu \mathrm{g} / \mathrm{duct}$ PLD was injected into all ten ducts at one time. The same injection was repeated 1 week or 4 weeks after the first injection.

\section{Mammary cell preparation}

Single cell suspensions were made from freshly separated mammary glands of mice by digestion and analyzed by flow cytometry [5]. In brief, mammary glands were digested for 8 hours at $37^{\circ} \mathrm{C}$ in serum-free breast tissue digestion medium (Stampfer protocol) [8] with collagenase $(80.0 \mathrm{mg} / 50 \mathrm{~mL})$ and hyaluronidase $(12.5 \mathrm{mg} / 50$ $\mathrm{mL})$. Organoids gained after vortexing were subjected to red blood cell lysis in a red blood cell lysing buffer (Sigma-Aldrich, St. Louis, MO, USA), dissociation in $0.25 \%$ trypsin for 2 minutes, $5 \mathrm{mg} / \mathrm{mL}$ dispase (StemCell Technologies, Vancouver, BC, Canada) with 0.1 $\mathrm{mg} / \mathrm{mL}$ DNase I (StemCell Technologies) for 2 minutes, and filtered through a $40 \mu \mathrm{m}$ mesh to gain single cells. Cells were incubated with biotinylated StemSep mouse/human chimera cocktail (StemCell Technologies) to block Fc receptor antibodies and anti-CD31 in order to label hematopoietic $\mathrm{CD}^{+} 5^{+} / \mathrm{Ter} 119^{+}$cells and endothelial cells.

\section{Flow cytometric analyses and fluorescence-activated cell sorting}

Anti-CD49f-APC (clone GoH3) (R\&D system, Minneapolis, MN, USA) and anti-CD24-PE (clone M1/69) (BD Pharmingen, San Jose, CA, USA) were used to identify the mammary epithelial cell populations. Staining for ALDH activity used the Aldefluor reagent (StemCell Technologies) according to the manufacturer's instructions. After the addition of $2 \mu \mathrm{g} / \mathrm{mL}$ propidium iodide (BD Pharmingen) to discriminate dead cells, cells were analyzed and/or sorted with a FACSAria (BD Biosciences, San Jose, CA, USA) as previously described [9].

\section{In vivo limiting dilution assay}

Mammary cells were produced as single cell suspensions from each $\mathrm{FVB} / \mathrm{N}$ mouse. Cells were resuspended in a $10 \mu \mathrm{L}$ volume containing 25\% Matrigel and 75\% Hank's balanced salt solution (StemCell Technologies) plus 2\% FBS. Cells $\left(10^{6}, 10^{5}, 10^{4}, 10^{3}, 10^{2}\right.$, 10) were instilled into cleared mammary fat pads of 3-week-old recipient FVB/N female mice. After 5-8 weeks, mammary glands were removed and carmine alum-stained for whole mount analysis. Fat pads were scored as positive or negative based on the presence or absence of mammary ductal outgrowths. Limiting dilution assays used "statmod" software package for the "R" computing environment (R Foundation for Statistical Computing, Vienna, Austria; http://www.R-project.org). The frequency of mammary repopulating units (MRUs) in single cell suspensions was calculated using complementary log-log generalized linear model. Two-sided 95\% Wald confidence intervals were computed, except in cases of zero outgrowths, when one-sided 95\% Clopper-Pearson intervals were used instead. The single-hit assumption was tested as recommended and was not rejected for any dilution series.

\section{RESULTS}

Mammary cells from i.duc PLD-treated and normal mouse mammary glands have similar flow cytometry profiles

MaSCs have been reported to be enriched in the subset of mam- 

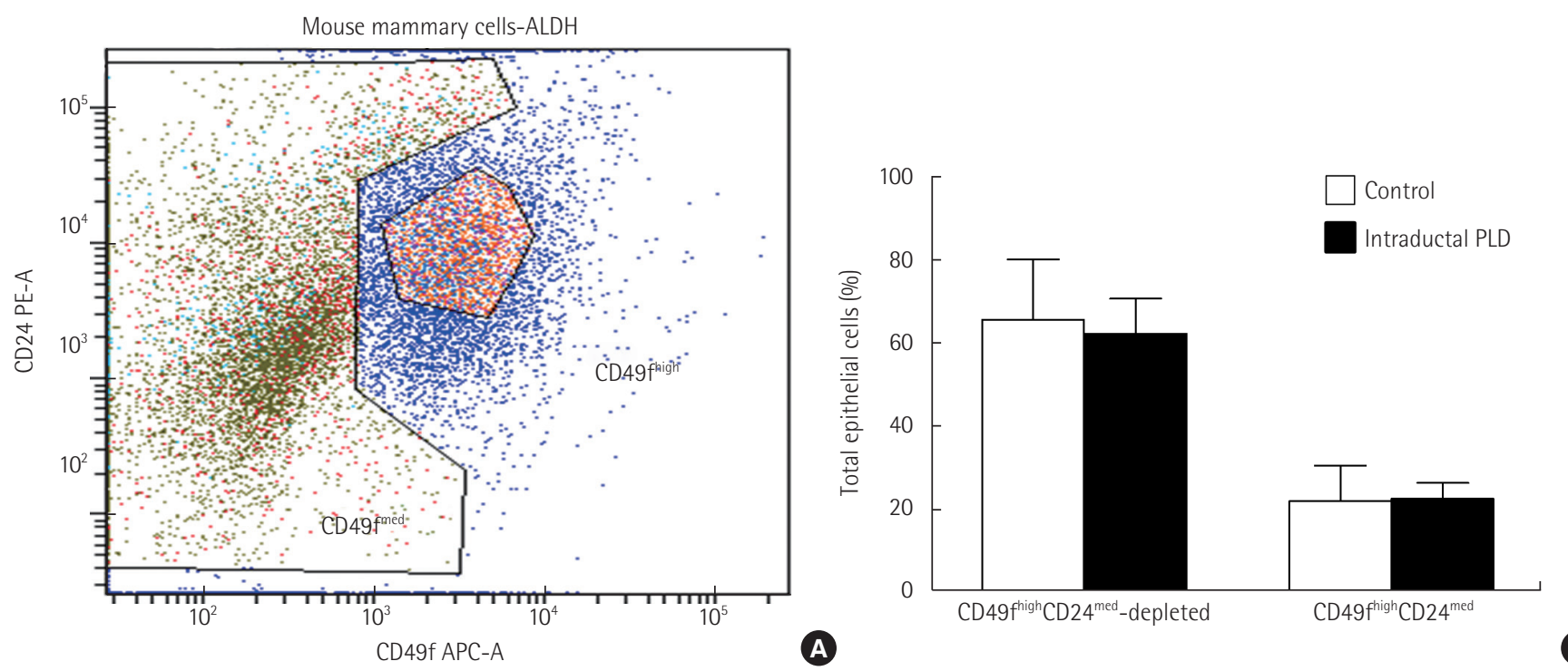

Fig. 1. Mammary epithelial cells from intraductal PLD-treated and control groups show similar mammary stem cell-enriched populations. (A) Primary mouse mammary epithelial cells were separated into $\mathrm{CD} 49 \mathrm{f}^{\text {high }} \mathrm{CD} 24^{\text {med }}$ and $\mathrm{CD} 49 \mathrm{f}^{\text {high }} \mathrm{CD} 24^{\text {med }}$-depleted populations using flow cytometry. (B) The percentage of cells in the stem cell-enriched and stem cell-depleted populations is shown. ALDH, aldehyde dehydrogenase; PLD, pegylated liposomal doxorubicin.

mary cells that are $\mathrm{Lin}^{-} \mathrm{CD} 49^{\text {figh }} \mathrm{CD} 24^{\mathrm{med}}$, or $\mathrm{Lin}^{-} \mathrm{CD} 29^{\text {high }} \mathrm{CD}$ $24^{\text {med }}[5,6]$. To determine whether i.duc PLD treatment changes the CD49fCD24 flow cytometry profile of mammary cells, in particular, whether changes occur to a stem-cell-enriched population, we used the well-established $\mathrm{CD} 49 \mathrm{f}^{\text {high }} \mathrm{CD} 24^{\text {med }}$ antigen phenotype to enrich mouse MaSCs. Primary mouse mammary epithelial cells were separated into $\mathrm{CD} 49 \mathrm{f}^{\text {high }} \mathrm{CD} 24^{\text {med }}$ and $\mathrm{CD} 49 \mathrm{f}^{\text {high }} \mathrm{CD}$ $24^{\text {med }}$-depleted populations using flow cytometry (Fig. 1A). We observed no change in the proportion of MaSC $\left(\mathrm{CD} 49 \mathrm{f}^{\text {high }} \mathrm{CD}\right.$ $24^{\text {med }}$ ) fraction in i.duc PLD-treated group compared with untreated group. The percentage of $\mathrm{CD} 49 \mathrm{f}^{\text {high }} \mathrm{CD} 24^{\text {med }}$ cells as a percentage of total epithelium in i.duc PLD-treated mice was $22.4 \% \pm$ $3.79 \%$ (mean \pm standard deviation; $\mathrm{n}=4$ independent preparation), and in control untreated mice the percentage was $21.8 \% \pm$ $8.59 \%(n=4$ independent preparation $)$ (Fig. 1B). There was also no significant difference between the proportions of $\mathrm{CD} 49 \mathrm{f}^{\text {high }} \mathrm{CD}$ $24^{\text {med }}$-depleted cells in i.duc PLD-treated mouse mammary glands compared with control mice (Fig. 1B).

\section{Cleared fat pad transplant analysis with $\mathrm{CD} 49 \mathrm{f}^{\text {high }} \mathrm{CD} 24^{\text {med }}$ mammary cells showed significantly decreased mammary outgrowth potential in i.duc PLD-treated mice compared with control untreated mice}

To evaluate ductal tree regeneration potential, serial dilution transplantation into epithelium cleared mammary fat pad was performed. We used this assay to compare the ability of cells isolated

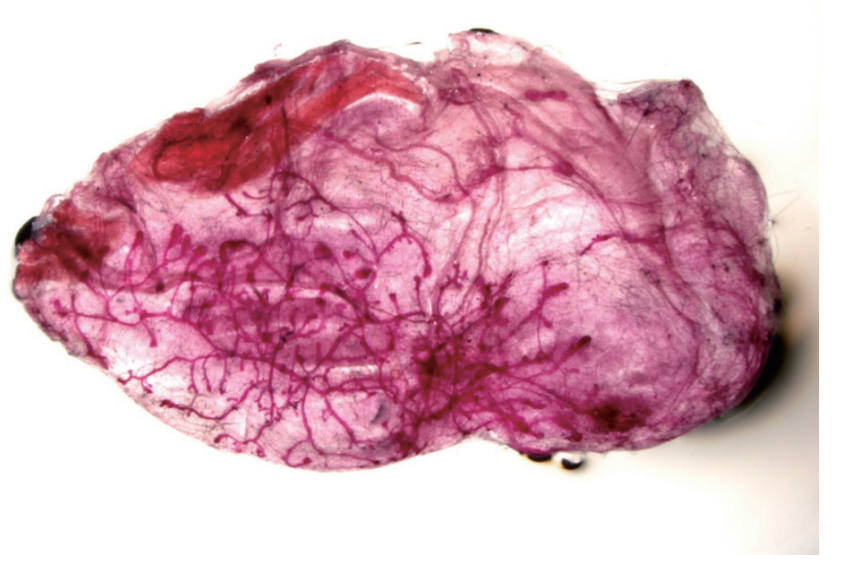

Fig. 2. Representative images of a cleared mouse mammary fat pad reconstituted.

from i.duc PLD-treated mice and control mice to repopulate a cleared mammary fat pad. Limiting dilution assays were used by transplanting $\mathrm{CD} 49^{\text {figh }} \mathrm{CD} 24^{\text {med }}$ mammary cells from each group into cleared mammary fat pads of 3-week-old FVB/N recipient mice. The cells were freshly isolated and did not undergo any in vitro culture period prior to transplantation. Transplants were examined after 5-8 weeks and number of outgrowths and the extent to which they filled the mammary fat pads were estimated (Fig. 2). The rate of successful transplants was used to estimate the proportion of MaSC in each population using the L-Calc analysis package [6]. i.duc PLD-treated mammary cells showed a mammary repop- 
Table 1. Effect of intraductal PLD on mammary repopulation in Lin ${ }^{-} \mathrm{CD} 49 \mathrm{f}^{\text {high }} \mathrm{CD} 24^{\text {med }}$ mammary epithelial cells

\begin{tabular}{|c|c|c|}
\hline \multirow{2}{*}{ No. of cells injected per mammary fat pad } & \multicolumn{2}{|c|}{ No. of outgrowths ${ }^{\text {a) }}$} \\
\hline & Control & Intraductal PLD \\
\hline \multicolumn{3}{|l|}{ CD49f figh $C D 24^{\text {med }}$ cells } \\
\hline $10^{5}$ & - & $4 / 12$ \\
\hline $10^{4}$ & $4 / 4$ & $4 / 27$ \\
\hline $10^{3}$ & $8 / 12$ & $2 / 26$ \\
\hline $10^{2}$ & $2 / 18$ & $1 / 14$ \\
\hline 10 & $0 / 12$ & $3 / 16$ \\
\hline Repopulating frequency & $1 / 910$ & $1 / 88,520$ \\
\hline $95 \% \mathrm{Cl}$ & $(1 / 1,161-1 / 199)$ & $(1 / 162,069-1 / 48,349)$ \\
\hline
\end{tabular}

Limiting dilution analysis of the repopulating frequency of $\mathrm{CD} 49 \mathrm{f}^{\text {high }} \mathrm{CD} 24^{\text {med }}$ mammary epithelial cells from control and intraductal pegylated liposomal doxorubicin (PLD)-treated glands transplanted into wild-type recipients. Cells were injected into cleared mammary fat pads of 3-week-old syngenic recipient mice and collected 5-8 weeks after transplantation. There was 97-fold decrease in absolute number of mammary repopulating unit in intraductal PLD-treated mammary glands.

$\mathrm{Cl}$, confidence interval.

a) $\mathrm{P}<0.0001$.
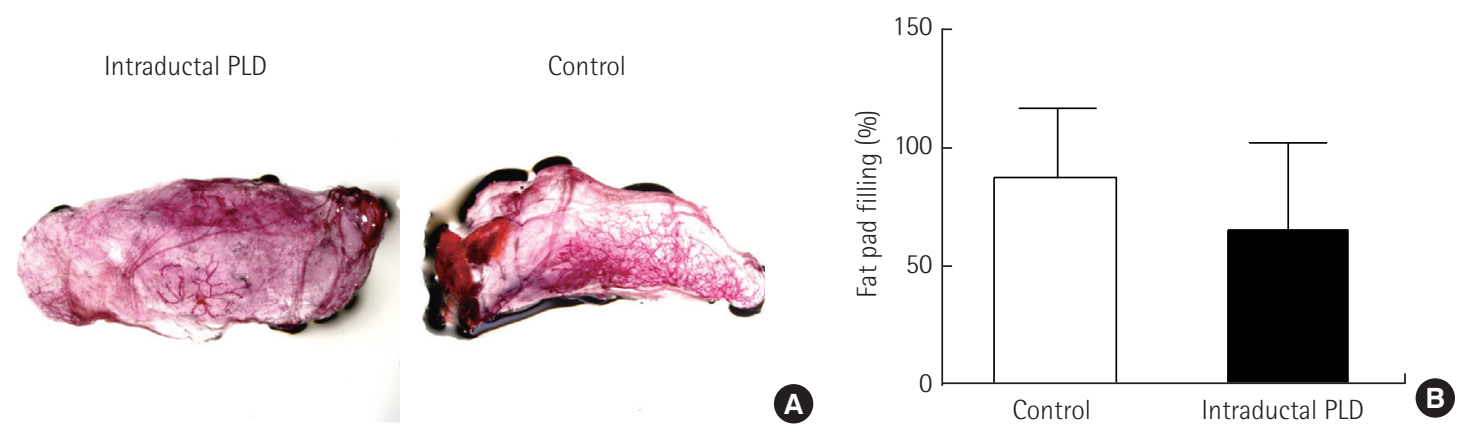

Fig. 3. Outgrowth from unsorted cells from intraductal pegylated liposomal doxorubicin (PLD)-treated mammary glands filled less portion of mammary fat pad. (A) A representative image of the extent of the cleared fat pad filled by outgrowths by cells from intraductal PLD-treated and control mammary glands. (B) Bar chart showing percentage fat pad filling by outgrowths from $10^{4}$ unsorted cells from control and intraductal PLD-treated mammary glands.

ulating unit frequency of 1 in 88,520 compared to 1 in 910 in untreated control mammary cells based on positive outgrowths scored for each cell dilution, demonstrating a 97-fold decrease in the absolute number of mammary repopulating units (Table 1).

The extent of fat pad filled by primary mammary epithelial cells from i.duc PLD-treated mammary glands was lesser than that from control untreated mice

The outgrowths from $10^{4}$ primary epithelial cells isolated from i.duc PLD-treated mice filled a lesser portion of cleared mammary fat pads, on average, compared to untreated control mice (65\% vs. 87.2\%) (Fig. 3). These data indicated that normal MaSC function, expressed by outgrowth potential, was reduced in the cells isolated from i.duc PLD treated-glands (Fig. 4).

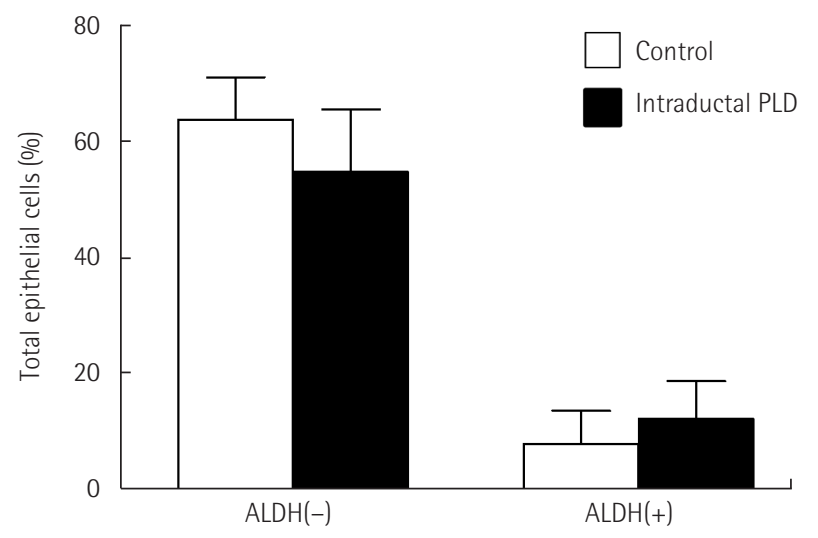

Fig. 4. ALDH(+) cell population was increased in cells from intraductal pegylated liposomal doxorubicin (PLD)-treated mammary glands compared with control glands. The percentage of cells in the $\mathrm{ALDH}(+)$ and $\mathrm{ALDH}(-)$ populations in each group are shown. ALDH, aldehyde dehydrogenase. 

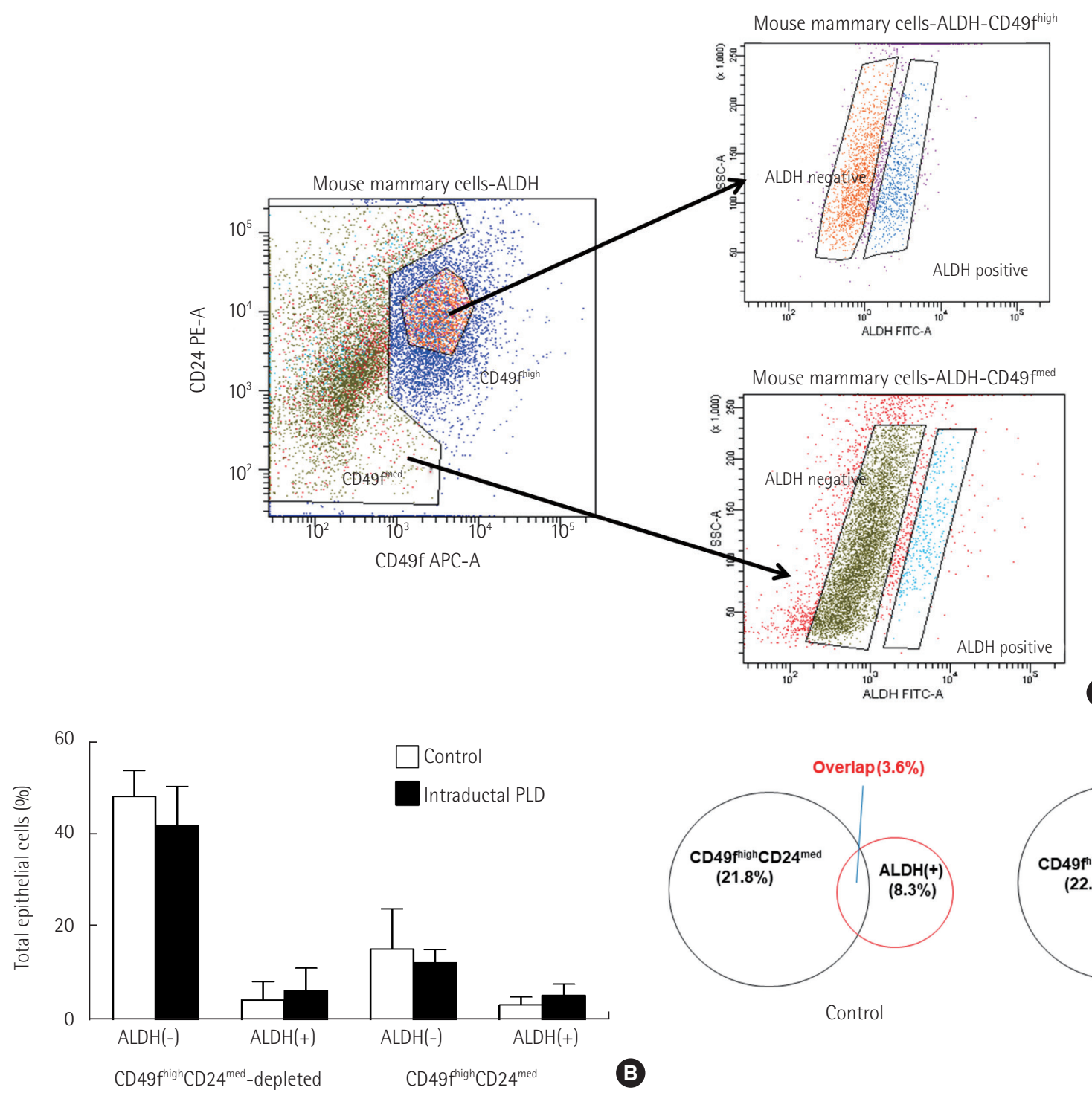

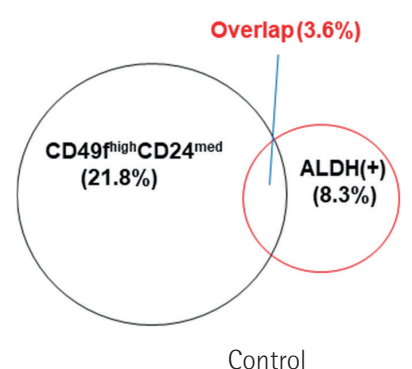

B

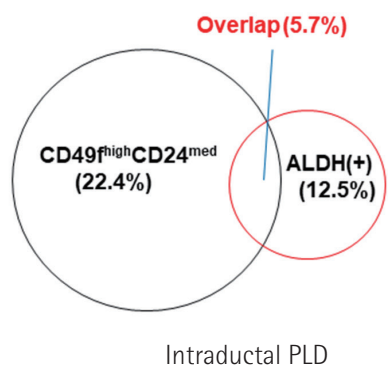

C

Fig. 5. Aldehyde dehydrogenase (ALDH) activity may add further selection of mammary stem cells (MaSCs) to CD49f CD24 in mouse mammary glands. (A) Primary mouse mammary epithelial cells were separated through the two-step process into $C D 49 f^{\text {high }} \mathrm{CD} 24^{\text {med }} \mathrm{ALDH}(+), \mathrm{CD}-$ $49^{\text {figh }} \mathrm{CD} 24^{\text {med }} \mathrm{ALDH}(-), \mathrm{CD} 4$ ff $^{\text {high }} \mathrm{CD} 24^{\text {med }}$-depleted $\mathrm{ALDH}(+)$ and $\mathrm{CD} 49 \mathrm{f}^{\text {high }} \mathrm{CD} 24^{\text {med }}$-depleted $\mathrm{ALDH}(-)$ populations using flow cytometry. (B) $\mathrm{ALDH}(+)$ population was increased in both $\mathrm{CD} 49 \mathrm{f}^{\text {high }} \mathrm{CD} 24^{\text {med }}$ and $\mathrm{CD} 49 \mathrm{f}^{\text {high }} \mathrm{CD} 24^{\text {med }}$-depleted cells from intraductal pegylated liposomal doxorubicin (PLD)-treated mammary glands. (C) The percentage shown in the diagram show the representation of the cell subpopulations in the total cell population and the overlap between the $\mathrm{ALDH}(+)$ and $\mathrm{CD} 49^{\text {high }} \mathrm{CD} 24^{\text {med }}$ phenotype. $\mathrm{CD} 4 \mathrm{f}^{\text {high }} \mathrm{CD} 24^{\text {med }} \mathrm{ALDH}(+)$ cell population was significantly smaller than $\mathrm{CD} 49 \mathrm{f}^{\text {high }} \mathrm{CD} 24^{\mathrm{med}} \mathrm{ALDH}(-)$ cell population in both control and intraductal PLD-treated groups.

ALDH(+) cell population was increased in cells isolated from i.duc PLD-treated mammary glands compared with control glands

It was reported that normal and malignant human mammary epithelial cells with increased ALDH activity had stem-/progenitor-like properties and ALDH expression correlated with poor prognosis [10]. To our knowledge, there is no published report defining whether ALDH can function as a mouse MaSC marker in human mammary glands. We next analyzed cells from i.duc
PLD-treated and control mammary glands for the expression of ALDH. ALDH $(+)$ cell population was increased $(8.3 \pm 5.70$ vs. $12.6 \pm 6.51)$ and ALDH( $(-)$ population was decreased $(64.1 \pm 7.31$ vs. $55.1 \pm 10.81)$ in cells isolated from i.duc PLD-treated mammary glands compared with control glands (Fig. 4).

ALDH activity may add further selection of MaSCs to CD49f CD24 in mouse mammary glands

Next we investigated the overlap between the ALDH(+) popula- 
Table 2. Frequency of mammary outgrowths Lin`mammary cells defined by CD49f, CD24, and ALDH expression

\begin{tabular}{|c|c|c|}
\hline \multirow{2}{*}{ No. of cells injected per mammary fat pad } & \multicolumn{2}{|c|}{ No. of outgrowths ${ }^{\text {a) }}$} \\
\hline & Control & Intraductal PLD \\
\hline \multicolumn{3}{|l|}{$\mathrm{CD}_{49 f^{\text {high }}} \mathrm{CD} 24^{\text {med }}$ ALDH(+) cells } \\
\hline $10^{5}$ & - & $1 / 2$ \\
\hline $10^{4}$ & $4 / 4$ & $4 / 17$ \\
\hline $10^{3}$ & $4 / 4$ & $2 / 11$ \\
\hline $10^{2}$ & $2 / 10$ & $1 / 11$ \\
\hline 10 & 0/8 & $2 / 12$ \\
\hline Repopulating frequency & $1 / 118$ & $1 / 2,119$ \\
\hline $95 \% \mathrm{Cl}$ & $(1 / 280-1 / 50)$ & $(1 / 3,894-1 / 1,153)$ \\
\hline
\end{tabular}

Frequency of mammary outgrowths of mammary cells defined by CD49f, CD24, and aldehyde dehydrogenase (ALDH) expression. Mammary outgrowth frequency of $\mathrm{CD} 49 \mathrm{f}^{\text {high }} \mathrm{CD} 24^{\text {med }} \mathrm{ALDH}(+)$ and $\mathrm{CD} 49 \mathrm{f}^{\text {high }} \mathrm{CD} 24^{\text {med }} \mathrm{ALDH}(-)$ mammary epithelial cells from control and intraductal pegylated liposomal doxorubicin (PLD)-treated glands transplanted into wild-type recipients. Cells were injected into cleared mammary fat pads of 3-week-old syngenic recipient mice and collected 8 weeks after transplantation.

$\mathrm{Cl}$, confidence interval.

a) $\mathrm{P}<0.0001$.

tion and the $\mathrm{CD} 49 \mathrm{f}^{\text {high }} \mathrm{CD} 24^{\text {med }}$ phenotype cells. We analyzed cells from i.duc PLD-treated and control mammary glands for the co expression of CD49f, CD24 and ALDH markers (Fig. 5A). We purified $\mathrm{CD} 49 \mathrm{f}^{\text {high }} \mathrm{CD} 24^{\text {med }} \mathrm{ALDH}(+)$ cells by double-sorting and counted them before transplantation. ALDH(+) cell population was increased and $\mathrm{ALDH}(-)$ cell population was decreased in both $\mathrm{CD} 49 \mathrm{f}^{\text {thigh }} \mathrm{CD} 24^{\text {med }}$-depleted and $\mathrm{CD} 49 \mathrm{f}^{\text {high }} \mathrm{CD} 24^{\text {med }}$ cells isolated from i.duc PLD-treated mammary glands (Fig. 5B). Flow cytometry analysis showed that both $\mathrm{CD} 49 \mathrm{f}^{\text {high }} \mathrm{CD} 24^{\text {med }}$ and $\mathrm{ALDH}(+)$ phenotypes identified an overlapping cell fraction, representing 3.6\% and 5.7\% in control and i.duc PLD-treated groups, respectively (Fig. 5C). We tested the outgrowth potential of cells defined by both phenotypes in control mammary glands. i.duc PLD-treated mammary cells showed a mammary repopulating unit frequency of 1 in 2,119 compared to 1 in 118 in untreated control mammary cells based on positive outgrowths scored for each cell dilution, demonstrating an 18 -fold decrease in the absolute number of mammary repopulating units (Table 2). These data suggested that adding ALDH had the possibility of better selection of a marker for MaSC of mice.

\section{DISCUSSION}

Adult stem cells are long-lived, generally quiescent cells that produce new stem cells, and thereby maintain the stem cell reservoir, as well as more committed progeny, which repopulate the organ through proliferation $[11,12]$. When necessary, it can expand to produce a transiently amplified reservoir of progenitors to repopulate tissues.

The activity of MaSCs and their mitotic progeny is essential to normal mammary growth, differentiation and regeneration in consecutive cycles of pregnancy, lactation, and involution. An important feature of the mammary gland is the regenerative capability of its epithelium, which is demonstrated upon successive reproductive cycles [13]. The ductal cells are those that line the ducts of the mammary gland. Lobular cells form secretory acinar structures and, upon pregnancy and lactation, become alveolar cells that produce milk proteins. The capability to recruit the mammary gland through cycles of pregnancy, lactation, and involution throughout a woman's lifetime is attributed to stem cells that are suggested to reside in the mammary gland $[14,15]$.

Mouse MaSCs have been shown to be enriched in Lin $^{-} \mathrm{CD} 49 \mathrm{f}-$ ${ }^{\text {high }} \mathrm{CD} 24^{\text {med }}$, or $\mathrm{CD} 29 \mathrm{f}^{\text {high }} \mathrm{CD} 24^{+}$mammary cells $[5,6]$. However, changes in the number of stem cells can hardly be detected by examining these stem cell-enriched populations as a whole because the poor extent of stem cell enrichment [7]. It has been shown that murine and human hematopoietic and neural stem and progenitor cells have high ALDH activity [16,17]. Increased ALDH activity has also been found in stem cell populations in multiple myeloma and acute myeloid leukemia $[17,18]$. It has been reported that ALDH is a marker of normal and malignant human MaSCs and a predictor of poor clinical outcome [19]. ALDH activity may thus provide a common marker for normal mouse MaSCs. However, little is known about the relation between ALDH activity and mouse MaSCs [19].

Here, we show ALDH activity may add further selection of MaSCs to CD49f CD24 in mouse mammary glands. CD49f figh $\mathrm{CD} 24^{\mathrm{med}} \mathrm{ALDH}(+)$ cell population shows more enrichment of mouse MaSCs than CD49f $\mathrm{f}^{\text {high }} \mathrm{CD} 24^{\text {med }}$ cell population. The percentage of $\mathrm{ALDH}(+)$ cells in the $\mathrm{CD} 49 \mathrm{f}^{\text {figh }} \mathrm{CD} 24^{\text {med }}$ population in- 
creased after i.duc PLD treatment (3.6\% vs. 5.7\%) because i.duc PLD injection is considered to damage a greater portion of normal mammary cells; and stem cell portions increase relatively.

In conclusion, we present that i.duc administration of PLD reduces MaSC function, but not the number, and ALDH activity may add further selection of MaSCs to CD49f CD24 in mouse mammary glands though more study is needed to underpin and strengthen this result. Screening of chemotherapeutic drugs or other natural products by this method of stem cell analysis may provide safe i.duc treatment in breast cancer. More research with various chemotherapeutic agents and adverse effect monitoring is needed.

\section{CONFLICT OF INTEREST}

No potential conflict of interest relevant to this article was reported.

\section{ACKNOWLEDGMENTS}

The authors would like to thank Saraswati Sukumar and Richard J. Jones at the Sidney Kimmel Comprehensive Cancer Center at Johns Hopkins for giving advice about intraductal injection and stem cell analysis.

\section{REFERENCES}

1. Murata S, Kominsky SL, Vali M, Zhang Z, Garrett-Mayer E, Korz D, et al. Ductal access for prevention and therapy of mammary tumors. Cancer Res 2006;66:638-45.

2. Stearns V, Mori T, Jacobs LK, Khouri NF, Gabrielson E, Yoshida T, et al. Preclinical and clinical evaluation of intraductally administered agents in early breast cancer. Sci Transl Med 2011;3:106ral08.

3. Chun YS, Bisht S, Chenna V, Pramanik D, Yoshida T, Hong SM, et al. Intraductal administration of a polymeric nanoparticle formulation of curcumin (NanoCurc) significantly attenuates incidence of mammary tumors in a rodent chemical carcinogenesis model: Implications for breast cancer chemoprevention in at-risk populations. Carcinogenesis 2012;33:2242-9.

4. Chun YS, Yoshida T, Mori T, Huso DL, Zhang Z, Stearns V, et al. Intraductally administered pegylated liposomal doxorubicin reduces mammary stem cell function in the mammary gland but in the long term, induces malignant tumors. Breast Cancer Res Treat 2012;135:201-8.

5. Stingl J, Eirew P, Ricketson I, Shackleton M, Vaillant F, Choi D, et al.
Purification and unique properties of mammary epithelial stem cells. Nature 2006;439:993-7.

6. Shackleton M, Vaillant F, Simpson KJ, Stingl J, Smyth GK, Asselin-Labat ML, et al. Generation of a functional mammary gland from a single stem cell. Nature 2006;439:84-8.

7. Siwko SK, Dong J, Lewis MT, Liu H, Hilsenbeck SG, Li Y. Evidence that an early pregnancy causes a persistent decrease in the number of functional mammary epithelial stem cells: implications for pregnancy-induced protection against breast cancer. Stem Cells 2008;26:3205-9.

8. Stampfer M, Hallowes RC, Hackett AJ. Growth of normal human mammary cells in culture. In Vitro 1980;16:415-25.

9. Matsui W, Wang Q, Barber JP, Brennan S, Smith BD, Borrello I, et al. Clonogenic multiple myeloma progenitors, stem cell properties, and drug resistance. Cancer Res 2008;68:190-7.

10. Ginestier C, Hur MH, Charafe-Jauffret E, Monville F, Dutcher J, Brown M, et al. ALDH1 is a marker of normal and malignant human mammary stem cells and a predictor of poor clinical outcome. Cell Stem Cell 2007;1:555-67.

11. Molofsky AV, Pardal R, Morrison SJ. Diverse mechanisms regulate stem cell self-renewal. Curr Opin Cell Biol 2004;16:700-7.

12. Reya T, Morrison SJ, Clarke MF, Weissman IL. Stem cells, cancer, and cancer stem cells. Nature 2001;414:105-11.

13. Smith GH. Stem cells and mammary cancer in mice. Stem Cell Rev 2005;1:215-23.

14. Williams JM, Daniel CW. Mammary ductal elongation: differentiation of myoepithelium and basal lamina during branching morphogenesis. Dev Biol 1983;97:274-90.

15. Smith GH, Chepko G. Mammary epithelial stem cells. Microsc Res Tech 2001;52:190-203.

16. Armstrong L, Stojkovic M, Dimmick I, Ahmad S, Stojkovic P, Hole $\mathrm{N}$, et al. Phenotypic characterization of murine primitive hematopoietic progenitor cells isolated on basis of aldehyde dehydrogenase activity. Stem Cells 2004;22:1142-51.

17. Matsui W, Huff CA, Wang Q, Malehorn MT, Barber J, Tanhehco Y, et al. Characterization of clonogenic multiple myeloma cells. Blood 2004;103:2332-6.

18. Pearce DJ, Taussig D, Simpson C, Allen K, Rohatiner AZ, Lister TA, et al. Characterization of cells with a high aldehyde dehydrogenase activity from cord blood and acute myeloid leukemia samples. Stem Cells 2005;23:752-60.

19. Stingl J. Detection and analysis of mammary gland stem cells. J Pathol 2009;217:229-41. 